NBER WORKING PAPER SERIES

\title{
ACADEMIC ENGAGEMENT, COMMERCIALIZATION, AND SCHOLARSHIP: EMPIRICAL EVIDENCE FROM AGRICULTURAL AND LIFE SCIENTISTS AT U.S. LAND-GRANT UNIVERSITIES
}

\author{
Bradford L. Barham \\ Jeremy D. Foltz \\ Ana Paula Melo \\ Working Paper 26688 \\ http://www.nber.org/papers/w26688
NATIONAL BUREAU OF ECONOMIC RESEARCH
1050 Massachusetts Avenue
Cambridge, MA 02138
January 2020

Thanks to Petra Moser and participants at the NBER Research and Innovation in Agriculture meeting for comments, Jordan Van Rijn and Josh Alfonso for data work, and USDA-AFRI and USDA-Hatch grants for funding. The views expressed herein are those of the authors and do not necessarily reflect the views of the National Bureau of Economic Research.

NBER working papers are circulated for discussion and comment purposes. They have not been peer-reviewed or been subject to the review by the NBER Board of Directors that accompanies official NBER publications.

(C) 2020 by Bradford L. Barham, Jeremy D. Foltz, and Ana Paula Melo. All rights reserved. Short sections of text, not to exceed two paragraphs, may be quoted without explicit permission provided that full credit, including $\odot$ notice, is given to the source. 
Academic Engagement, Commercialization, and Scholarship: Empirical Evidence from Agricultural and Life Scientists at U.S. Land-grant Universities

Bradford L. Barham, Jeremy D. Foltz, and Ana Paula Melo

NBER Working Paper No. 26688

January 2020

JEL No. I23,O31

\begin{abstract}
This article examines the involvement of agricultural and life science faculty at U.S. land grant universities in two types of university-industry relations: academic engagement (sponsored research, industry collaborations, and presentations), academic commercialization (patenting, licensing, and start-ups) and traditional academic scholarship. It exploits large-scale, random sample cross-section surveys of nearly 1,500 scientists at the original 52 Land Grant Universities in 2005 and 2015. We fill a knowledge gap regarding the prevalence, coincidence, intensity, importance and factors shaping faculty involvement in university-industry relations (UIR). After several decades of promotion and emphasis on UIR activities participation in them has plateaued and is stable at a fairly high level. Academic engagement is far more prevalent (at $76 \%$ of faculty) and important than is academic commercialization (at $19 \%$ of faculty). Academic engagement generates 15-20 times the research funds than academic commercialization does, but both continue to be dwarfed by public funding. We find evidence of synergies between UIR activities and academic scholarship. We also explore how individual, institutional, and universitylevel factors help explain faculty UIR participation. We find differences across academic disciplines and highlight the role that faculty attitudes toward science and commercial activity shape involvement in UIR. Significant differences also stem from university level effects and may be contingent on culture, history, location, and quality of science.
\end{abstract}

Bradford L. Barham

Dept. of Ag. \& Applied Economics University of Wisconsin, Madison 427 Lorch St.

Madison, WI 53706

bradford.barham@wisc.edu

Jeremy D. Foltz

Dept. of Ag. \& Applied Economics

University of Wisconsin, Madison

427 Lorch St.

Madison, WI 53706

jdfoltz@wisc.edu
Ana Paula Melo

Dept. of Ag. \& Applied Economics

University of Wisconsin, Madison

427 Lorch St.

Madison, WI 53706

melodasilva@wisc.edu 


\section{Introduction}

Research on the factors shaping University-Industry Relations (UIR) has exploded in recent decades, as reflected by the hundreds of recent articles published on this topic. ${ }^{1}$ At the heart of this take-off was the push by universities worldwide to pursue opportunities to commercialize intellectual property rights. Arguably, the 1981 passage of the Bayh-Dole Act put U.S. public research universities at the forefront of this global expansion. It expanded the intellectual property rights of American universities and their researchers to commercialize innovations and discoveries associated with federally sponsored research (Henderson and Jaffee, 1998; Grimaldi et al., 2011; Sampat, 2006; Thursby and Thursby 2011). European and universities elsewhere followed suit to varying degrees. In the process, UIR around the globe expanded traditional scholarship models of publishing and training students into directly engaging with industry and entering commercial domains via patents, start-ups, and other forms of corporate-university alliances.

Our study sheds light on the ground-level of UIR at leading U.S. Land-Grant Universities (LGUs) by examining the activities, attitudes, and research choices of individual agricultural and life science faculty. At LGUs, faculty engagement with industry dates back to the end of the 19th century based on an explicit emphasis on practical agricultural and engineering sciences, formal extension appointments for faculty, and ongoing outreach with farms and firms to improve their performance. The recent salience of UIR activities to U.S. LGUs stems from the considerable financial stress they faced over the past three decades due to significant declines in state and federal support (Just and Huffman, 2009; Ehrenberg, 2012; Hoag, 2005). ${ }^{2}$ Hence, most U.S. LGUs pursued academic commercialization as a potential mechanism to generate royalties and start-up revenue streams (Thursby and Thursby, 2011).

Our article exploits rich and unique, representative individual-level cross-sectional and panel survey data gathered in 2005 and 2015 from agricultural and life science faculty from all 52 of the

\footnotetext{
${ }^{1}$ See for example: Agrawal, 2001; Djokovic and Souitarius, 2008; Geuna and Muscio, 2009; Perkmann et al. 2013; Sengupta and Ray, 2017.

${ }^{2}$ For example, compared to the $2007 / 08$ school year, state spending on higher education, which is a significant portion of Land Grant University budgets nationwide was down in 2015 by $23 \%$ or $\$ 2,026$ per student (Mitchell, Palacios, Leachman; 2015)
} 
original 1863 U.S. Land Grant Universities. We explore the prevalence, intensity, and importance of U.S. land-grant faculty's work with industry as compared to traditional scholarship activities. We also examine how faculty attitudes toward research choices shape their participation in UIR, and how they combine UIR with traditional scholarship activities. We divide university industry relations into two types. ${ }^{3}$ One is academic engagement (AE), defined as faculty participation in sponsored and collaborative research, contract research, consulting, and informal relationships with private firms and institutions. Academic commercialization (AC) is the other, defined as faculty participation in private intellectual property creation (via invention disclosures, patents, and licensing) and entrepreneurship (e.g., start-ups). These definitions are used in other recent articles that examine UIR among university faculty in Europe (D'Este and Perkmann, 2011; Perkmann et al., 2011; Tartari et al., 2014; Tartari and Salter, 2015; Sengupta and Ray, 2017).

These apparently contrasting categories are not mutually exclusive types of UIR, with many faculty doing both academic engagement and commercialization (AE/AC). In our analysis we contrast faculty who engage in these three categories - engagement (AE), commercialization (AC), and both $(\mathrm{AE} / \mathrm{AC})$ - with faculty who are not engaged in any of the three, which we categorize as "Traditional Scholar" (TS) . ${ }^{4}$ Together these four categories (AE, AC, AE/AC, and TS) characterize how university faculty engage with industry.

We address four major questions: What is the prevalence and intensity of 'academic engagement' and 'academic commercialization' activities among agricultural and life science faculty at flagship public research universities across the United States? What role does UIR play in funding faculty research? How do the research and teaching outputs of faculty active in UIR activities compare to those of Traditional Scholars? And, last but certainly not least, how do the UIR activities and attitudes of land grant agricultural and life science faculty align with researcher motivations for their choice of research problem? Because UIR activities "tend to be individually driven and pursued on a discretionary basis," (Perkmann et al. 2015, p. 424), we examine them

\footnotetext{
${ }^{3}$ We follow the classification adopted in Perkmann et al (2013).

${ }^{4}$ We are cognizant of the long-standing tradition of faculty, especially at Land-Grant Universities, engaging with industry. Our nomenclature is meant to distinguish between the traditional activities of teaching and research with UIR.
} 
at the individual faculty level where we can probe how they meet the values and motivations of faculty. Participation largely depends on the 'independent initiative of autonomous, highly skilled' faculty pursuing research and knowledge transfer activities that they value for scientific and/or commercial reasons.

Our work builds on several recent research contributions, and is especially motivated by the Perkmann et al. (2013) review on faculty activity in university industry relations. They identify three major information gaps, which we address directly in this paper. One is the lack of comparative evidence from U.S. universities regarding faculty engagement in distinct types of UIR activities, since the literature is mostly based on European university data. They also document surprisingly little examination of the two UIR activities (engagement and commercialization) sideby-side and the factors shaping faculty engagement with them. Although there is a vast body of research on academic commercialization and its impacts on faculty scholarship (Agarwal and Henderson, 2002; Azoulay et al. 2007), relatively little research compares and contrasts it with the full set of possible ways for faculty to engage with industry, as we do here. The third is the lack of temporal - including longitudinal - evidence that allows attention to trends over time of innovation in UIR. This is now a relatively mature episode, with the academic commercialization take-off in the U.S. having occurred by the 1990s and in Europe not long afterwards, which warrants study.

Other recent papers help to motivate this article. Sengupta and Ray (2017) probe the dynamic relationship between both types of UIR (what they call Knowledge Transfer) and traditional research outputs at UK research universities. Using a longitudinal, university-level dataset (spanning 2008-14), they find that both academic engagement and academic commercialization are positively associated with past research performance. However, consistent with the higher prevalence and intensity of academic engagement relative to academic commercialization in UK universities, they also show that only the former has strong positive feedback effects on subsequent research performance, both via funding and research scholarship (using both quantity and quality measures). This major finding in the UK helps to set the broad stage for our analysis of UIR and research activities among individual agricultural and life science faculty in the major U.S. Land-Grant universities. 
In D'Este and Perkmann's (2011), they distinguish between two ways in which faculty attitudes toward UIR may shape their participation. In the first, faculty are viewed as academic entrepreneurs who seek to engage in UIR for commercialization reasons, what we refer to as commercial motivation. In the second, faculty are viewed as scientists operating in a 'strongly institutionalized environment' who mainly seek UIR collaborations to advance their research efforts, what we later call intrinsic motivation. We recover these motivations from our data using factor analysis of attitudinal questions and then in a similar fashion to D'Este and Perkmann (2011) link them to faculty activity choices.

Finally, Perkmann et al. (2013), as well as Sengupta and Ray (2017), highlight the potential importance of university level infrastructure, research quality, and incentives for promotion and salary increases in shaping faculty engagement with UIR activities. Specifically, the historical experience and current resource base associated with university technology transfers offices can positively shape UIR outcomes. Likewise, universities with higher quality research performance may be more attractive to industry partners and thus attract UIR. Cutting the other way is the possibility that faculty at the very top universities, especially in some fields, may be less inclined toward applied research and UIR relative to pursuing large public or foundation grants and peerbased collaborations.

Our analysis of the data on LGU faculty answers the four research questions as follows. First, at U.S. LGUs, academic engagement, which includes sponsored research, industry collaborations, and presentations, is far more prevalent and intensively pursued than is academic commercialization, which includes patenting, licensing, and start-ups. Several decades into the LGU push toward commercialization, faculty participation appears to have plateaued at much lower levels than their academic engagement. And, additional longitudinal evidence shows that academic engagement is the more steadily pursued form of UIR, while academic commercialization appears to be more opportunistic, perhaps consistent with the notion that only occasional scientific breakthroughs are worthy of a patent.

Second, commercialization generates very low levels of revenue streams for the operation of 
LGU faculty research labs. By contrast, funding generated by sponsored research of various sorts (including continued support from commodity organizations) outpaces commercialization revenues by a ratio of about 15:1, and represents for many faculty a substantive portion of their research lab expenditures. Nonetheless, public funding, especially federal funds, continue to be the majority source of faculty lab funding. Thus, while academic engagement is far more important as a revenue stream for faculty research activities than is commercialization, it remains overall a distant second to public funds.

Third, consistent with many previous studies we find that UIR activities of both types are higher among faculty with higher levels of traditional academic scholarship outputs. Thus, UIR and academic scholarship appear to be synergistic, reflecting at an individual level the dynamic feedbacks identified by Sengupta and Ray (2017) in UK data at a university level. This 'synergy' finding also implies that concerns about major trade-offs between faculty UIR activity and traditional academic scholarship may be off track. Indeed, they appear to overlook a positive dynamic feedback loop that can nourish more of both types of activity over time.

Finally, the regression analysis reveals that individual, institutional, and university-level factors all help to explain faculty UIR activity. As found elsewhere, attitudes and activity choice align in ways consistent with faculty participating in UIR for reasons related to advancing scientific research rather than pursuing commercialization outcomes. The university-level fixed effect results are also intriguing, as they suggest that higher levels of UIR activity are contingent on culture, history, location, and quality of science associated with the overall university (not just individual faculty).

The next section describes the context of colleges of agriculture and life sciences at U.S. Land Grant Universities, while section 3 introduces the data and explains our methods. Section 4 presents the results, while section 5 discusses the implications of our findings for UIR in the U.S. Section 6 concludes. 


\section{U.S. Land-Grant Universities}

Three major legislative acts frame the longstanding tradition of academic engagement at US LGUs (Fitzgerald et al. 2016). The first is the Morrill Act of 1862 which granted states land to help finance the establishment of public universities. They emphasized agricultural and mechanical arts in support of those two major economic sectors, while broadening access to education and training. The second is the Hatch Act of 1887 which provided funding to land-grant universities to invest in agricultural experimental stations. It recognized the value of increasing public commitment to research that advanced knowledge for both farmers and consumers with respect to production and nutrition/health outcomes. Finally, the Smith-Lever Act of 1914 created the infrastructure for delivering knowledge to society via an extension system. It aimed at both sharing research discoveries with farmers, firms, and consumers and identifying future research issues based on feedback from those and other 'stakeholders'. Combined, these three acts shaped a long and rich history of 'academic engagement' at US LGUs that featured colleges of agriculture (and later 'life sciences') as the cutting-edge of UIR activities. Some faculty appointments included explicit attention to 'extension' in combination with traditional scholarship: research and instruction duties.

Faculty in US colleges of agricultural and life sciences generally span the breadth of basic and applied sciences reflected across the rest of public research universities. Some departments are filled primarily with mostly basic scientists. This holds especially in "biology" departments, such as genetics, molecular biology, and biochemistry, as well as in "ecology" departments (of various names). There are mostly applied (but some basic) scientists in animal science departments (including specialties in dairy or poultry science), food and nutrition science departments, plant science departments (including agronomy, entomology, horticulture, plant pathology, and soil science), and agricultural or biosystems engineering. Finally, colleges of agriculture and life sciences have social scientist departments of various names that include economists, sociologists, journalism and communications, and regional planning and community development faculty. While most of these social scientists tend to work on more 'applied' questions, there are also some who could be viewed as closer to 'basic' in their orientation to pursuing advances on 'theory' and 'measurement' 
issues rather than emphasizing applied questions. Thus, the fields in US LGUs tend to provide distinctive 'institutional' contexts in which to frame the likely connections between faculty and UIR activities.

In the 1990s, as with other universities, academic commercialization efforts took off in US Land Grant University colleges of agriculture and life sciences (Barham et al. 2002; Foltz et al. 2003; Sampat, 2006). Biotechnology patents especially were viewed as a potential source of growth and expansion in both UIR and revenue streams for universities and faculty inventors. A plethora of literature explores this period (Phan and Siegel, 2006; Grimaldi et al., 2011), with a primary focus on whether academic activities and the pursuit of open science would be advanced or reduced by the attention to commercialization efforts (Thursby and Thursby, 2011). At the 'field level', this AC push arguably expanded the potential for higher levels of faculty participation in UIR among more basic scientists who might be able to pursue patents on discoveries more readily than they might seek out sponsored research or active collaboration with industry scientists. Thus, it is arguable that AC engagement may be higher among biologists, but the longstanding engagement with AE activities by the more applied scientists could also readily give rise to patenting and commercialization efforts depending on the research topics and discoveries being pursued. These cross-cutting trends make it difficult to envision a clear distinction in terms of AC participation across the natural science fields. On the other hand, social scientists are far less likely to be engaged with patenting and licensing efforts. Most of their 'idea' discoveries are likely to be algorithms and statistical or system modeling innovations rather than material ones. As a result, $\mathrm{AC}$ participation among social scientists is likely to be lower than other types of science faculty in colleges of agriculture and life sciences.

The rise in US LGU efforts to promote AC coincided with a secular decline in federal and state support for higher education (Ehrenberg, 2012). While LGUs were initially able to largely compensate for that decline by raising tuition fees, significant pressures on the research and salary expenditures were experienced especially between 2005 and 2015 (Mitchell, Palacios, Leachman, 2015). During that time period, most LGUs experienced an overall decline in state revenues. Faculty increasingly experienced real declines in salary levels as well as increased pressure to pursue 
extramural funding of various types - including UIR - to support their labs and their salaries (American Academy of Arts \& Sciences, 2016). Indeed, many colleges of agricultural and life sciences pursued conversions of faculty salary contracts from 12-month to 9-month appointments. Faculty were 'incentivized' to pursue the additional 3 months of salary through external sources or 'administrative' postings. All of these changes could potentially be viewed as commercial or financial motivations to increase both $\mathrm{AE}$ and $\mathrm{AC}$ efforts, if in fact they held potential for filling holes in research budgets and faculty summer salary needs.

Two other contextual trends in US LGUs warrant attention here. One is the pressure on research time associated with 'changes' in university budgets. As documented in Barham et al. (2014), US LGU agricultural and life science faculty reported declines in 'research time' and concomitant increases in time spent on administrative activities. Reducing support staff and increasing faculty reporting efforts is one way in which LGUs dealt with budget cuts and compliance demands. This could have put pressure on faculty to limit UIR as part of the overall pressure on their time, especially research time. The other one, which is 'more speculative', is the potential for morale issues associated with this long period of budget pressures and time constraints. It seems likely that these could either have dampened enthusiasm for UIR activities (exhaustion) or increased incentives for faculty to pursue especially commercial links for more personal gain.

\section{Data, Methods and Descriptive Statistics}

This paper is based on data collected in surveys of agricultural and life science faculty conducted in 2005 and 2015. In each data collection effort we administered a survey to nearly 3,000 agricultural and life science faculty at all of the U.S. 1863 LGUs. ${ }^{5}$ Both surveys had a sample frame that included all tenure-track faculty scientists in agricultural and life science departments at these land-grant universities. We culled faculty names from university web directories to create the cross-sectional sample frame and then randomly selected a sample of scientists who were sent a web-based survey with follow-up paper-mail reminders as in Dillman (2011). In addition to

\footnotetext{
${ }^{5}$ The Institutional Review Board at UW-Madison approved both of these surveys, with the latest approval being \#2015-0924
} 
the random samples in both years, we also re-sampled respondents from the 2005 survey in 2015 in order to have longitudinal data on 244 faculty. The response rate in 2015 was $31 \%$ based on respondents who answered at least one survey question, with a higher response rate in 2005 of $60 \%$.

Response rates in 2015 did vary somewhat by discipline, from a high of $42 \%$ among plant scientists (the largest discipline represented) to only $28 \%$ among agricultural engineering scientists (the smallest discipline). We accept the null hypothesis of no response rate bias (see Barham et al. 2017) with respect to the following observed characteristics: field, gender, faculty size of the agricultural college, total university research funding, or total full-time university student enrollment. In Appendix A we report further sample restrictions. Our final sample for analysis, from the random sample data collection, covers 881 scientists in 2005 and 598 in 2015 across all 52 LGUs. We also report some results from the longitudinal sample of scientists surveyed in both years.

Table 1 details the set of questions with respect to faculty University-Industry Relations (UIR) activities in our data. Academic engagement activities span a similar range described in the aforementioned studies in the UK. They cover collaborations, sponsored research by industry (and commodity organizations), presentations to industry or farmers, and research problem identification. Likewise, academic commercialization activities span invention disclosures, patenting, licensing, product development, and start-ups. 
Table 1: Types of university-industry relations and survey items included

\begin{tabular}{|c|c|c|c|}
\hline 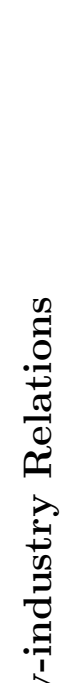 & $\begin{array}{c}\text { Academic } \\
\text { Engagement }\end{array}$ & $\begin{array}{l}\text { Faculty } \\
\text { participation in } \\
\text { sponsored and } \\
\text { collaborative } \\
\text { research, contract } \\
\text { research, and } \\
\text { information } \\
\text { relationships with } \\
\text { private firms and } \\
\text { institutions. }\end{array}$ & $\begin{array}{l}\text { Survey item description } \\
\text { Research support from private industry } \\
\text { Research support from commodity organizations } \\
\text { Collaborated with scientists in private industry } \\
\text { Co-authored with scientists in private industry } \\
\text { Presented to farmers or farm organizations } \\
\text { Presented to commodity groups } \\
\text { Presented to the private industry } \\
\text { Farmers or farm org. helped you identify } \\
\text { a research problem } \\
\text { Collaborated on a research project with farmers } \\
\text { or farm org. } \\
\text { Co-authorship on paper or patent with farmers } \\
\text { or farm org. }\end{array}$ \\
\hline 光 & $\begin{array}{c}\text { Academic } \\
\text { Commercialization }\end{array}$ & $\begin{array}{c}\text { Faculty } \\
\text { participation in } \\
\text { private intellectual } \\
\text { property creation - } \\
\text { via invention } \\
\text { disclosure, patents, } \\
\text { and licensing - and } \\
\text { entrepreneurship } \\
\text { (e.g. start-ups). }\end{array}$ & $\begin{array}{l}\text { Licensing or patenting revenue. } \\
\text { \# disclosures generated } \\
\text { \# patent applications generated } \\
\text { \# patents issued } \\
\text { \# patents licensed out } \\
\text { \# products under regulatory review generated } \\
\text { \# products on the market generated } \\
\text { \# start-up companies founded }\end{array}$ \\
\hline
\end{tabular}

We use these UIR related items in the data to construct categorical variables of academic engagement and commercialization participation measures, as well as ones that identify when individuals do both. We identify individuals not fitting in any UIR category as Traditional Scholars. The participation measure is 'liberal' in the sense that participating in any of the academic engagement or commercialization activities identifies an individual with that category. We use these categorical variables to describe trends in UIR participation on the 'extensive' margin.

In addition to individual participation in university-industry relations, the subsequent analysis also focuses on other faculty research activities. We mostly focus on published articles, training of graduate students, and receipt of research funding. Those research activities are incorporated into the comparisons of faculty across UIR categories in order to help identify the potential for 
synergies or trade-offs between UIR and traditional scholarship outcomes. Similarly, we use data on total research grant revenues and different sources of revenue, such as federal, state, industry, commodity groups, foundations, and licensing revenues.

Two other important sets of measures from the survey warrant description here. First, in both 2005 and 2015 surveys, respondents were asked about the reasons motivating them to pursue a certain research topic in the last five years. They are generally oriented toward 'intrinsic' motivations, such as 'scientific curiosity' or 'potential contribution to scientific theory', or extrinsic ones,

such as 'potential marketability' or 'potential to patent and license the discovery'. The full set of 14 questions are shared in Table 8. The items are in a 1-5 Likert-type scale with a score of 1 being "not at all" and a score of 5 being "Extremely". Responses to these questions are examined using factor analysis in order to uncover latent factors that might shape faculty research choice. That approach is also more fully described in the Appendix, reporting on the actual factor loadings. We use the loadings to identify the block of items that with internal consistency. We calculate indexes for each measure of intrinsic and extrinsic motivations. Indexes are calculated as the response average for the block of items within each factor as reported in Table 9.

\subsection{Descriptive Statistics}

We start with three broad observations that start to frame U.S. Land-Grant Universities (LGU) participation in university-indsutry-relations (UIR) activities. They can be gleaned from Tables 2, 3, and 4. Table 2 provides a comparison for 2005 and 2015 of the prevalence of each of the UIR activities. Table 3 provides a comparison over time of faculty participation in the four UIR categories. In Table 4 we describe participation rates in academic engagement and commercialization UIR activities by gender, rank, appointment type, and field. 
Table 2: AE and AC Activity Participation Rates and Counts, 2005 and 2015

\begin{tabular}{|c|c|c|c|c|c|}
\hline \multirow[t]{2}{*}{ Academic Engagement } & \multicolumn{2}{|c|}{2005} & \multicolumn{2}{|c|}{2015} & \multirow[t]{2}{*}{$\Delta$ p.p. } \\
\hline & Rate & Count & Rate & Count & \\
\hline Had research support from private industry & 0.47 & 413 & 0.45 & 277 & -1.83 \\
\hline Had research support from commodity organizations & 0.32 & 279 & 0.29 & 177 & -2.89 \\
\hline Collaborated with scientists in private industry & 0.29 & 256 & 0.36 & 220 & $6.76^{* * *}$ \\
\hline Co-authored with scientists in private industry & 0.12 & 109 & 0.15 & 93 & 2.77 \\
\hline Presented to farmers or farm organizations & 0.41 & 361 & 0.38 & 233 & -3.09 \\
\hline Presented to commodity groups & 0.32 & 282 & 0.31 & 189 & -1.27 \\
\hline Presented to the private industry & 0.32 & 278 & 0.30 & 181 & -2.12 \\
\hline $\begin{array}{l}\text { Had help from farmers or farm organizations to you } \\
\text { identify a research problem }\end{array}$ & 0.38 & 329 & 0.38 & 232 & 0.39 \\
\hline Collaborated on a research project with farmers & & & & & \\
\hline or farm organizations & 0.27 & 238 & 0.31 & 192 & $4.23^{* *}$ \\
\hline $\begin{array}{l}\text { Co-authorship on paper or patent with farmers } \\
\text { or farm organizations }\end{array}$ & 0.03 & 29 & 0.03 & 18 & -0.37 \\
\hline Commercial Engagement & \multicolumn{2}{|c|}{2005} & \multicolumn{2}{|c|}{2015} & $\Delta$ p.p. \\
\hline & Rate & Count & Rate & Count & \\
\hline $\begin{array}{l}\text { Received any royalties income from patent } \\
\text { (past } 5 \text { years) }\end{array}$ & 0.04 & 35 & 0.04 & 27 & 0.42 \\
\hline Had licensing or patenting revenue returned & & & & & \\
\hline to your research lab (last year) & 0.03 & 24 & 0.04 & 22 & 0.86 \\
\hline Number of disclosures generated & 0.15 & 135 & 0.13 & 81 & -2.16 \\
\hline Number of patent applications generated & 0.16 & 141 & 0.11 & 68 & $-4.97 * * *$ \\
\hline Number of patents issued & 0.10 & 89 & 0.06 & 39 & $-3.78^{* *}$ \\
\hline Number of patents licensed out & 0.05 & 41 & 0.04 & 22 & -1.08 \\
\hline Number of products under regulatory review generated & 0.02 & 20 & 0.01 & 9 & -0.81 \\
\hline Number of products on the market generated & 0.07 & 64 & 0.05 & 29 & $-2.56^{* *}$ \\
\hline Number of start-up companies founded & 0.04 & 35 & 0.03 & 17 & -1.21 \\
\hline
\end{tabular}

We find that U.S.-LGU faculty participation rates in UIR activities are high, with an average of $78 \%$ of faculty participating in some type of UIR (Table 2). Consistent with other evidence in the literature, academic engagement (AE) is far more prevalent than commercialization (AC), with about $75 \%$ of LGU faculty pursuing AE as compared to about $20 \%$ in some type of AC. Moreover, if we isolate on the AC only category in Table 3, we find that around $2-3 \%$ of faculty are just doing $\mathrm{AC}$ in the two time periods. In other words, the vast majority of faculty engaged in $\mathrm{AC}$ activities are also active in $\mathrm{AE}$. The proportion of faculty that are not engaged in UIR, the 
traditional scholarship (TS) category, is greater than the total proportion active in AC. Thus, AC participation is the least prevalent in the mix of faculty engagement types examined here.

UIR participation declined somewhat between 2005 and 2015. Declines in commercialization activities led the way, with a 6 percentage point decline from $25 \%$ of respondents in 2005 to $19 \%$ in 2015 . When we look at the four exclusive measures, this change concentrates in faculty moving from practicing both engagement and commercialization (AE/AC) to engamement (AE) only. Academic engagement participation was essentially unchanged. The decline in academic commercialization between 2005 and 2015 contradicts the expected increase based on universitylevel commercialization promotion in previous decades. We conclude that the popular perception following university rhetoric on expansion of UIR activities is not borne out by the behavior of LGU faculty in terms of engaging with industry in commercialization activities.

Table 3: Faculty participation rates in UIR, 2005 and 2015

\begin{tabular}{lccc}
\hline \hline & 2005 & 2015 & Diff. \\
\hline Academic Engagement (AE) (AC) & 0.75 & 0.76 & -0.01 \\
Academic Commercialization (A & 0.26 & 0.19 & $0.07^{* *}$ \\
& & & \\
Multually exclusive measures & & & \\
Academic Engagement (AE) - Exclusively & 0.53 & 0.60 & $-0.07^{* *}$ \\
AC and AE & 0.22 & 0.17 & $0.06^{* *}$ \\
Academic Commercialization (AC) - Exclusively & 0.03 & 0.02 & 0.01 \\
Traditional Scholarship & 0.21 & 0.21 & 0.00 \\
\hline \hline
\end{tabular}

Across fields, participation varies between 60-90\% of faculty engaging in UIR, as detailed in Table 4. We performed statistical tests to identify the differences across categories. There is statistically significant variation at a $95 \%$ level across gender, with men being on average 6 percentage points more likely to engage in UIR than women. We find no statistically significant differences in participation by appointment type and/or level. In terms of field of study differences, the highest rates are in applied/production agricultural disciplines while the lowest UIR participation rates are in the 60-70\% range for the biological, ecological and social sciences. This outcome is also consistent with findings from the UK mentioned above, where more basic research is associated with relatively lower UIR activity. 
Table 4: Individual characteristics of UIR categories, 2005 and 2015

\begin{tabular}{|c|c|c|c|c|c|c|c|c|}
\hline & \multicolumn{4}{|c|}{2005} & \multicolumn{4}{|c|}{2015} \\
\hline & $\mathrm{AE}$ & $\mathrm{AE} / \mathrm{AC}$ & $\mathrm{AC}$ & TS & $\mathrm{AE}$ & $\mathrm{AE} / \mathrm{AC}$ & $\mathrm{AC}$ & TS \\
\hline Gender & & & & & & & & \\
\hline Male & 0.54 & 0.23 & 0.03 & 0.20 & 0.58 & 0.19 & 0.02 & 0.21 \\
\hline Female & 0.49 & 0.19 & 0.04 & 0.28 & 0.64 & 0.11 & 0.02 & 0.23 \\
\hline \multicolumn{9}{|l|}{ Rank } \\
\hline Professor & 0.48 & 0.25 & 0.03 & 0.23 & 0.57 & 0.21 & 0.02 & 0.20 \\
\hline Associate Professor & 0.61 & 0.20 & 0.03 & 0.17 & 0.65 & 0.09 & 0.01 & 0.25 \\
\hline Assistant Professor & 0.54 & 0.18 & 0.04 & 0.24 & 0.61 & 0.14 & 0.03 & 0.21 \\
\hline \multicolumn{9}{|l|}{ Fields } \\
\hline Ag Engineering & 0.53 & 0.37 & 0.04 & 0.06 & 0.59 & 0.22 & 0.04 & 0.15 \\
\hline Animal Science & 0.57 & 0.31 & 0.03 & 0.08 & 0.62 & 0.23 & 0.02 & 0.13 \\
\hline Biology & 0.22 & 0.28 & 0.10 & 0.40 & 0.37 & 0.21 & 0.10 & 0.33 \\
\hline Plant Science & 0.62 & 0.27 & 0.03 & 0.08 & 0.69 & 0.25 & 0.01 & 0.05 \\
\hline Ecology & 0.58 & 0.16 & 0.02 & 0.25 & 0.65 & 0.07 & 0.01 & 0.27 \\
\hline Food/Nutrition & 0.49 & 0.35 & 0.04 & 0.12 & 0.46 & 0.34 & 0.00 & 0.20 \\
\hline Social Sciences & 0.55 & 0.04 & 0.01 & 0.41 & 0.58 & 0.03 & 0.01 & 0.38 \\
\hline
\end{tabular}

$\mathrm{AE}=$ Academic Engagement; $\mathrm{AC}=$ Academic Commercialization. We define Traditional Scholarship (TS) as those that do not engage in either $\mathrm{AC}$ or $\mathrm{AE}$.

While suggestive of different norms, the decline in commercialization captured in the crosssection analyses might be a result of changes in the demographic composition of types of faculty. To control for potential demographic composition changes, we next investigate the individuals for which we have panel data to check for changes in individual faculty behavior over time. This smaller panel dataset was gathered as part of the ongoing study to probe the persistence of individual participation in each of the categories. Table 5 provides a transition matrix between 2005 and 2015 of UIR participation rates across the UIR categories. 
Table 5: Persistence in faculty participation in UIR

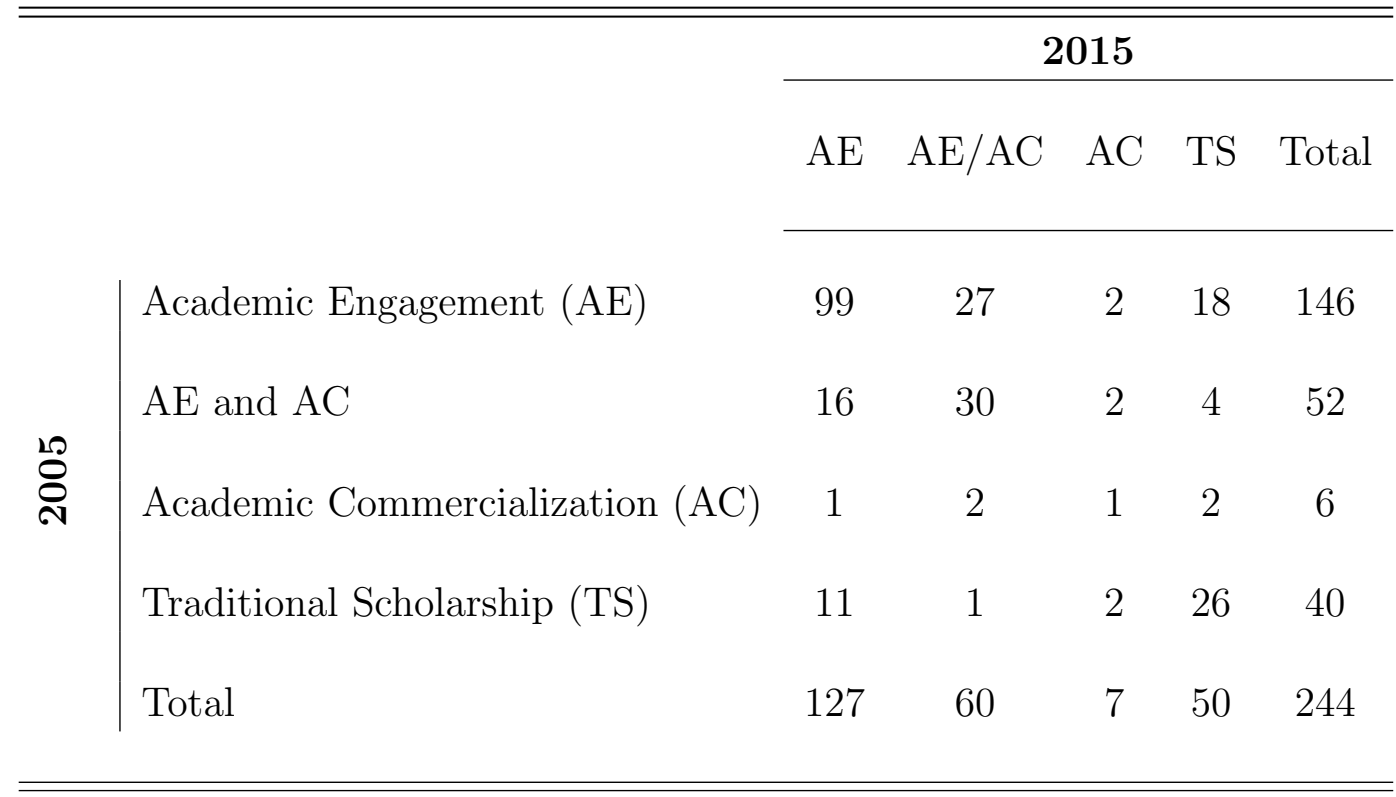

This tables reports results from the Panel data linking individuals between 2005 and 2015 waves.

We offer four observations based on the transition patterns in Table 5. First, academic engagement or mixed UIR categories show a higher rate of persistence over time that does commercialization only. There is a high exit rate out of academic commercialization reflected in the $\mathrm{AE} / \mathrm{AC}$ and $\mathrm{AC}$ rows, where only a little over half of faculty that were doing commercialization (AC) in 2000-05 stay engaged in AC activities in the 2010-15 time-period. By contrast, about 85-90\% of faculty who were engaged in academic engagement (AE) or both (AE/AC) activities in 2000-05 remain engaged with AE activities in 2010-15. Second, the commercialization (AC) category is by far the least likely to gain faculty across the two time periods, reflecting the low likelihood of faculty activity in just commercialization. In fact, the decline in $\mathrm{AC}$ evident in the cross-sectional data also shows up as a lack of persistence and a lack of new faculty entrants into this activity. Third, a transition to $\mathrm{AE} / \mathrm{AC}$ from any of the other categories is far more likely, suggesting the potential joint nature of academic engagement with academic commercialization rather than the move to commercialization as an independent activity. Fourth, $25 \%$ of traditional scholars transitioned to AE activities over time, but at the same time a larger number of scholars transitioned from the UIR categories into the TS category. Thus the traditional scholars category increases from $16 \%$ to $20 \%$ of the sample, showing its robustness to the purported increase in UIR emphasis at LGUs. 
Table 6 shows research funding for different UIR participation categories. It compares amounts of funding from different sources as well as the shares associated with each funding source. ${ }^{6}$ Across all of the UIR categories federal funding remains the primary source of research funds, with industry and commodity organizations playing a substantial but subordinate role. At less than $2 \%$ overall, licensing revenues from AC activities are a trivial source and they are 10 - 15 times smaller than the funds earned by faculty doing AE from private industry and commodity organization sources. Interestingly, faculty who earned patent royalties are only found within the AC faculty who also engages in AE. It is also worth noting that for the median research lab revenue, those associated with faculty engaged in $\mathrm{AC}$ and $\mathrm{AE} / \mathrm{AC}$ have the highest research funding levels across both years of data, although this pattern is less evident in the mean values. Both AE only and TS labs have, at the median, lower levels of funding.

\footnotetext{
${ }^{6}$ Note that "Private Industry" and "Commodity Organization" funding are used to define AE and "Patent Royalties" to define AC. Therefore, by definition, these amounts are zero for some UIR categories.
} 
Table 6: Research lab financial sources across UIR types, 2005 and 2015

\begin{tabular}{|c|c|c|c|c|c|c|c|c|c|}
\hline & & \multicolumn{4}{|c|}{2005} & \multicolumn{4}{|c|}{2015} \\
\hline & & $\mathrm{AE}$ & $\mathrm{AE} / \mathrm{AC}$ & $\mathrm{AC}$ & $\mathrm{TS}$ & $\mathrm{AE}$ & $\mathrm{AE} / \mathrm{AC}$ & $\mathrm{AC}$ & $\mathrm{TS}$ \\
\hline $\begin{array}{l}\text { Research Lab Revs } \\
\text { Median }\end{array}$ & $\$$ & 167,312 & 214,832 & 270,414 & 113,024 & 293,202 & 403,127 & 304,033 & 276,025 \\
\hline $\begin{array}{l}\text { Research Lab Revs } \\
\text { Mean }\end{array}$ & $\$$ & 75,000 & 150,000 & 103,000 & 75,000 & 100,000 & 200,000 & 200,000 & 60,000 \\
\hline Fed Grants & $\begin{array}{l}\$ \\
\%\end{array}$ & $\begin{array}{c}86,583 \\
38.14\end{array}$ & $\begin{array}{c}100,175 \\
40.76\end{array}$ & $\begin{array}{c}208,572 \\
57.42\end{array}$ & $\begin{array}{c}73,344 \\
47.86\end{array}$ & $\begin{array}{c}163,247 \\
38.38\end{array}$ & $\begin{array}{c}224,621 \\
43.96\end{array}$ & $\begin{array}{c}217,800 \\
65.15\end{array}$ & $\begin{array}{c}217,232 \\
50.83\end{array}$ \\
\hline State Grants & $\begin{array}{l}\$ \\
\%\end{array}$ & $\begin{array}{c}15,843 \\
9.34\end{array}$ & $\begin{array}{c}17,900 \\
6.33\end{array}$ & $\begin{array}{c}8,200 \\
8.08\end{array}$ & $\begin{array}{c}6,454 \\
7.91\end{array}$ & $\begin{array}{c}20,216 \\
8.14\end{array}$ & $\begin{array}{c}18,422 \\
5.18\end{array}$ & $\begin{array}{c}15,385 \\
3.08\end{array}$ & $\begin{array}{c}18,446 \\
5.30\end{array}$ \\
\hline Foundations & $\begin{array}{l}\$ \\
\%\end{array}$ & $\begin{array}{c}6,238 \\
4.17\end{array}$ & $\begin{array}{c}9,493 \\
3.60\end{array}$ & $\begin{array}{c}17,405 \\
4.48\end{array}$ & $\begin{array}{l}7,685 \\
7.16\end{array}$ & $\begin{array}{c}12,247 \\
5.99\end{array}$ & $\begin{array}{c}17,228 \\
5.06\end{array}$ & $\begin{array}{c}37,943 \\
11.00\end{array}$ & $\begin{array}{c}16,069 \\
6.23\end{array}$ \\
\hline University Funds & $\begin{array}{l}\$ \\
\%\end{array}$ & $\begin{array}{c}11,122 \\
10.93\end{array}$ & $\begin{array}{c}14,919 \\
7.86\end{array}$ & $\begin{array}{c}23,669 \\
15.69\end{array}$ & $\begin{array}{c}10,175 \\
15.42\end{array}$ & $\begin{array}{c}16,517 \\
11.06\end{array}$ & $\begin{array}{c}28,892 \\
9.44\end{array}$ & $\begin{array}{c}17,598 \\
14.23\end{array}$ & $\begin{array}{c}11,418 \\
13.85\end{array}$ \\
\hline Private Industry & $\begin{array}{l}\$ \\
\%\end{array}$ & $\begin{array}{c}16,546 \\
11.30\end{array}$ & $\begin{array}{c}35,322 \\
16.03\end{array}$ & - & - & $\begin{array}{c}36,574 \\
12.72\end{array}$ & $\begin{array}{c}69,626 \\
17.15\end{array}$ & - & - \\
\hline Commodity Orgs & $\begin{array}{l}\$ \\
\%\end{array}$ & $\begin{array}{c}7,256 \\
7.51\end{array}$ & $\begin{array}{c}11,137 \\
8.99\end{array}$ & $\begin{array}{l}- \\
-\end{array}$ & - & $\begin{array}{c}19,341 \\
8.90\end{array}$ & $\begin{array}{c}24,674 \\
7.92\end{array}$ & - & $\begin{array}{l}- \\
-\end{array}$ \\
\hline Patent Royalties & $\begin{array}{l}\$ \\
\%\end{array}$ & - & $\begin{array}{c}3,848 \\
1.14\end{array}$ & - & - & - & $\begin{array}{c}4,110 \\
1.42\end{array}$ & - & - \\
\hline Others & $\begin{array}{l}\$ \\
\%\end{array}$ & $\begin{array}{c}16,966 \\
16.67\end{array}$ & $\begin{array}{c}17,344 \\
12.24\end{array}$ & $\begin{array}{c}12,567 \\
14.32\end{array}$ & $\begin{array}{l}9,301 \\
15.80\end{array}$ & $\begin{array}{c}22,677 \\
11.81\end{array}$ & $\begin{array}{c}15,555 \\
8.89\end{array}$ & $\begin{array}{c}15,308 \\
6.54\end{array}$ & $\begin{array}{c}10,630 \\
16.16\end{array}$ \\
\hline
\end{tabular}

For each category of UIR, Table 7 reports on scholarly outputs: articles published in the last 5 years and being the main advisor for Ph.D. and Masters' students. Consistent with many other previous studies in the literature, academic outcomes are robust to faculty participation in UIR activities. The most active faculty in UIR, the AE/AC group have the highest article productivity (mean of 23 articles in 2010-15) and a similar number of Ph.D. students trained (mean of 2.5 in 2010-15) to the AC group (2.8). These compare to about 14 articles over 2010-15 for AE and TS categories and 1.6 Ph.D. students for those two categories. The high outputs of the AE/AC group are consistent with synergies between UIR and scholarly outputs that is found in econometric 
studies elsewhere (e.g., Foltz, Kim, \& Barham, 2003). Table 7 is also noteworthy for providing continued evidence of rising productivity over time of U.S.-LGU faculty based on article counts (Prager et al. 2014). ${ }^{7}$

Table 7: Scholarly outputs across UIR types, 2005 and 2015

\begin{tabular}{|c|c|c|c|c|c|c|c|c|}
\hline \multicolumn{9}{|c|}{2005} \\
\hline & \multicolumn{2}{|c|}{$\mathbf{A E}$} & \multicolumn{2}{|c|}{$\mathrm{AE} / \mathrm{AC}$} & \multicolumn{2}{|c|}{$\mathrm{AC}$} & \multicolumn{2}{|c|}{ TS } \\
\hline & Mean & Median & Mean & Median & Mean & Median & Mean & Median \\
\hline Scholarly articles (5 yrs) & 11.34 & 10 & 17.08 & 14 & 17.93 & 14 & 10.62 & 9 \\
\hline Master students (5 yrs) & 3.14 & 2 & 2.56 & 2 & 1.48 & 1 & 3.01 & 2 \\
\hline Ph.D students (5 yrs) & 1.25 & 1 & 1.81 & 1 & 1.83 & 1 & 1.76 & 1 \\
\hline \multicolumn{9}{|c|}{2015} \\
\hline & \multicolumn{2}{|c|}{$\mathrm{AE}$} & \multicolumn{2}{|c|}{$\mathrm{AE} / \mathrm{AC}$} & \multicolumn{2}{|c|}{$\mathrm{AC}$} & \multicolumn{2}{|c|}{ TS } \\
\hline & Mean & Median & Mean & Median & Mean & Median & Mean & Median \\
\hline Scholarly articles (5 yrs) & 14.45 & 12 & 23.45 & 19 & 19.92 & 13 & 14.59 & 12 \\
\hline Master students (5 yrs) & 2.79 & 2 & 2.41 & 2 & 1.85 & 1 & 1.78 & 1 \\
\hline PhD students (5 yrs) & 1.61 & 1 & 2.48 & 2 & 2.77 & 2 & 1.61 & 1 \\
\hline
\end{tabular}

We turn next to Table 8 showing the values or stated preferences of U.S.-LGU faculty with respect to their motivations for 'research problem choice'. We first report for both 2005 and 2015 the average scores (1 low to 5 high) for a select set of questions related to 'intrinsic motivations' versus 'extrinsic motivations' and compare them across UIR categories. Note first that in both years, 'enjoy the research' and 'scientific curiosity' scores average well above 4 for all categories of faculty. By contrast, the scores for 'potential marketability' or 'private firms commercialization interest' are lower for all of the UIR categories relative to intrinsic motivations, by at least a full point and often times two or three points.

\footnotetext{
${ }^{7}$ We make no effort to control for quality or potential increases in co-authorship either of which could lead to an adjustment in the raw measure provided here. The evidence from Foltz, Kim, \& Barham (2003) suggests quantity and quality (as measured by citations) are highly correlated, which suggests the bias from unmeasured quality could be small. We have no evidence on which way the bias from co-authorship patterns might go.
} 
Table 8: Research choice criteria across UIR types, 2005 and 2015

\begin{tabular}{|c|c|c|c|c|c|c|c|c|}
\hline \multirow[b]{2}{*}{ Research Choice Criteria } & \multicolumn{4}{|c|}{2005} & \multicolumn{4}{|c|}{2015} \\
\hline & $\mathrm{AE}$ & $\mathrm{AE} / \mathrm{AC}$ & $\mathrm{AC}$ & TS & $\mathrm{AE}$ & $\mathrm{AE} / \mathrm{AC}$ & $\mathrm{AC}$ & TS \\
\hline Enjoy doing this kind of research & 4.51 & 4.55 & 4.52 & 4.70 & 4.27 & 4.33 & 4.46 & 4.53 \\
\hline Potential contribution to scientific theory & 3.51 & 3.78 & 4.45 & 4.15 & 3.36 & 3.73 & 4.62 & 3.85 \\
\hline Scientific curiosity & 4.17 & 4.27 & 4.45 & 4.37 & 4.02 & 4.17 & 4.38 & 4.39 \\
\hline Probability of publication in professional journal & 3.88 & 3.90 & 4.17 & 4.18 & 3.82 & 3.90 & 4.46 & 4.03 \\
\hline Potential Marketability & 2.41 & 3.34 & 2.69 & 1.67 & 1.76 & 3.06 & 2.31 & 1.37 \\
\hline Availability of private and corporate funds & 2.86 & 3.34 & 2.14 & 1.72 & 2.84 & 3.48 & 2.08 & 1.89 \\
\hline Request made by clientele & 3.25 & 3.34 & 2.10 & 2.10 & 3.10 & 2.97 & 1.69 & 1.77 \\
\hline Feedback from extension personnel & 2.75 & 2.61 & 1.83 & 1.71 & 2.61 & 2.42 & 1.77 & 1.61 \\
\hline Potential to patent and license the findings & 1.47 & 2.48 & 2.38 & 1.17 & 1.20 & 2.46 & 1.92 & 1.11 \\
\hline Interest by private firms in commerc. the discovery & 1.78 & 2.76 & 2.21 & 1.24 & 1.45 & 2.66 & 1.77 & 1.15 \\
\hline Importance to society & 4.33 & 4.29 & 4.17 & 4.24 & 4.05 & 4.27 & 4.23 & 3.97 \\
\hline Approval of colleagues & 2.50 & 2.44 & 2.17 & 2.46 & 2.30 & 2.48 & 2.15 & 2.25 \\
\hline Availability of public funds & 3.96 & 4.09 & 4.10 & 3.69 & 3.77 & 4.14 & 4.15 & 3.51 \\
\hline Availability of research facilities & 3.44 & 3.88 & 3.24 & 3.15 & 3.29 & 3.89 & 4.31 & 2.87 \\
\hline
\end{tabular}

Note: These questions are reported using a 1-5 Likert-type scale, with a score of 1 being "not at all" and a score of 5 being "extremely".

We next use factor analysis to recover underlying factors explaining the variance in the motivations for research choices data. Two factors explain most of the variance in the data, which we identify as Intrinsic and Extrinsic Motivation factors. We constructed indexes (simple average) within the items identified as a factor. Some have consistent 'high loadings' within each identified factor, such as scientific curiosity or potential contribution to scientific theory, which we interpret as intrinsic motivation. Meanwhile, likely interest by private firms in commercializing the discovery and potential marketability of the final product "loads high" in what we interpret as extrinsic motivation. 
Table 9: Factor Loadings Estimation, after rotation

\begin{tabular}{lcc}
\hline \hline Item & Extrinsic & Intrinsic \\
\hline Potential contribution to scientific theory & & 0.61 \\
Probability of publication in professional journal & & 0.47 \\
Enjoy doing this kind of research & & 0.53 \\
Scientific curiosity & 0.51 & \\
Request made by clientele & 0.48 & \\
Feedback from extension personnel & 0.67 & \\
Potential to patent and license the research findings & 0.74 & \\
Interest by private firms in commercializing the discovery & 0.68 & \\
Potential Marketability & 0.51 & \\
Availability of private and corporate funds & & \\
Availability of research facilities & & \\
Approval of colleagues & & \\
Availability of public, state, and federal funds & \\
Importance to society &
\end{tabular}

Note: Factors are calculated jointly for both waves. Comparing eigenvalues and its variances we confirm the existence of two factors. Together, they explain 93\% of the variance. We used Principal Factor with orthogonal quartimax rotation to estimate the factor loadings. Measures on Intrinsic and Extrinsic motivations are calculated as the average of the items within each identified factor.

We show the distribution of the indexes by UIR category in Figure 1. In 2005 and 2015, faculty report higher mean intrinsic than extrinsic motivations when it comes to research problem choice. The distribution of intrinsic motivations is skewed to the right, averaging 4 points. Meanwhile, extrinsic motivation appears to be less important to faculty, averaging 2 points. Both measures decreased between 2005 and 2015, with the larger decrease in extrinsic motivation moving the distribution of that measure to be almost entirely distributed below "neutral". Meanwhile the intrinsic index, while decreasing remained strongly distributed in the very to extremely important zone. 
Figure 1: Distribution of Extrinsic and Intrinsic Incentives Indexes, pooled cross-section data.
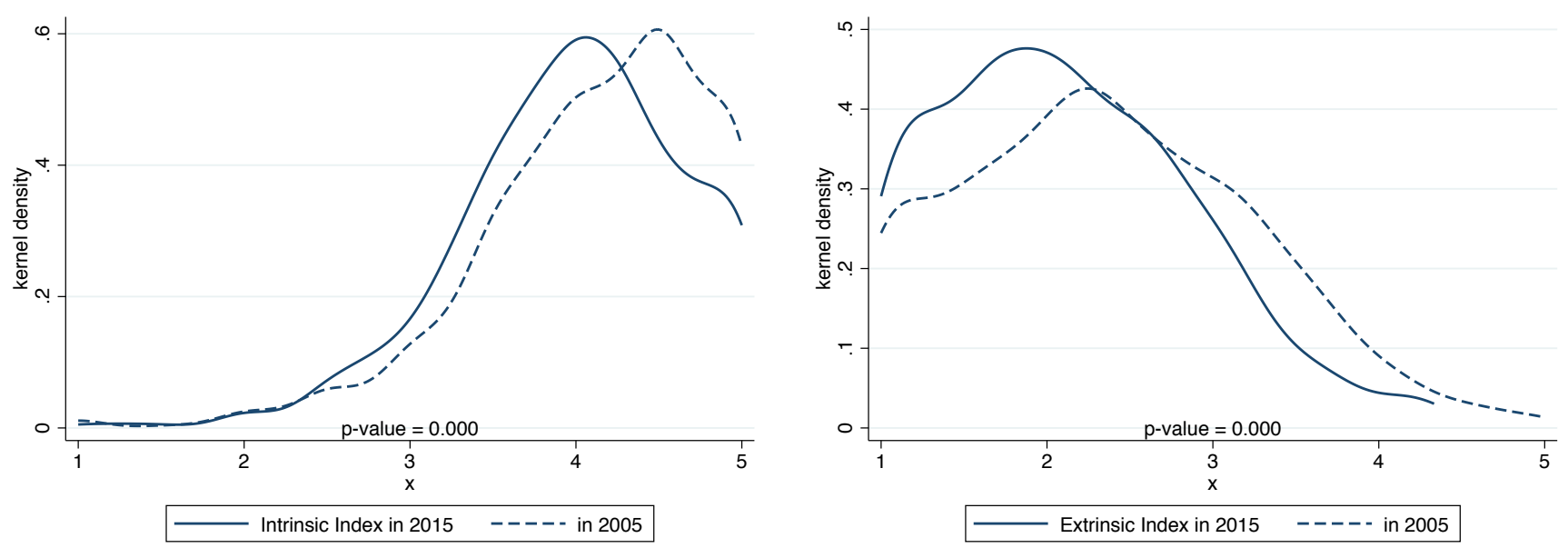

Note: This figure displays the distribution of the calculated intrinsic and extrinsic indexes from the cross-section data for individuals surveys both in 2005 and 2015.

In Figure 2 we report the distributions of the motivation indexes by UIR category. As would be expected by their actions, traditional scholars are skewed far to the right on intrinsic motivations and far to the left on commercial ones. Yet we see that both categories of academic commercialization ( $\mathrm{AC}$ and $\mathrm{AE} / \mathrm{AC}$ ) also have high levels of scientific motivation, with only academic engagement as distinctly below the others. AE/AC appears to show both the highest average levels of commercial motivation and the greatest diversity of motivations within the category, as exemplified by a flatter distribution. The Academic Commercialization only group shows high levels of intrinsic motivation as well as a bi-modal distribution of commercial motivation with some at both high and low levels. ${ }^{8}$

\footnotetext{
${ }^{8}$ Results for the exclusive Academic Commercialization category need to be interpreted with caution due to the small number of cases in our sample.
} 
Figure 2: Distribution of Intrinsic and Extrinsic motivation by UIR category, 2005 and 2015 pooled index

(a) Intrinsic Motivation

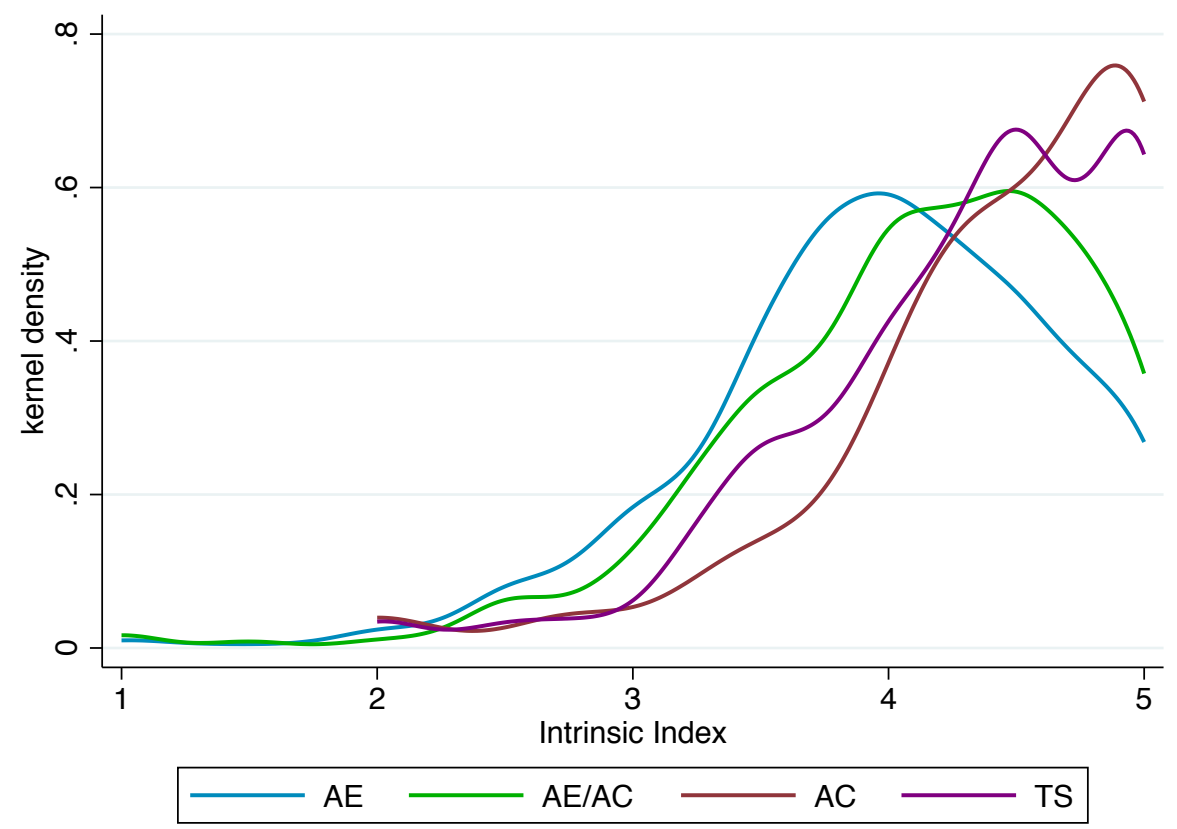

(b) Extrinsic Motivation

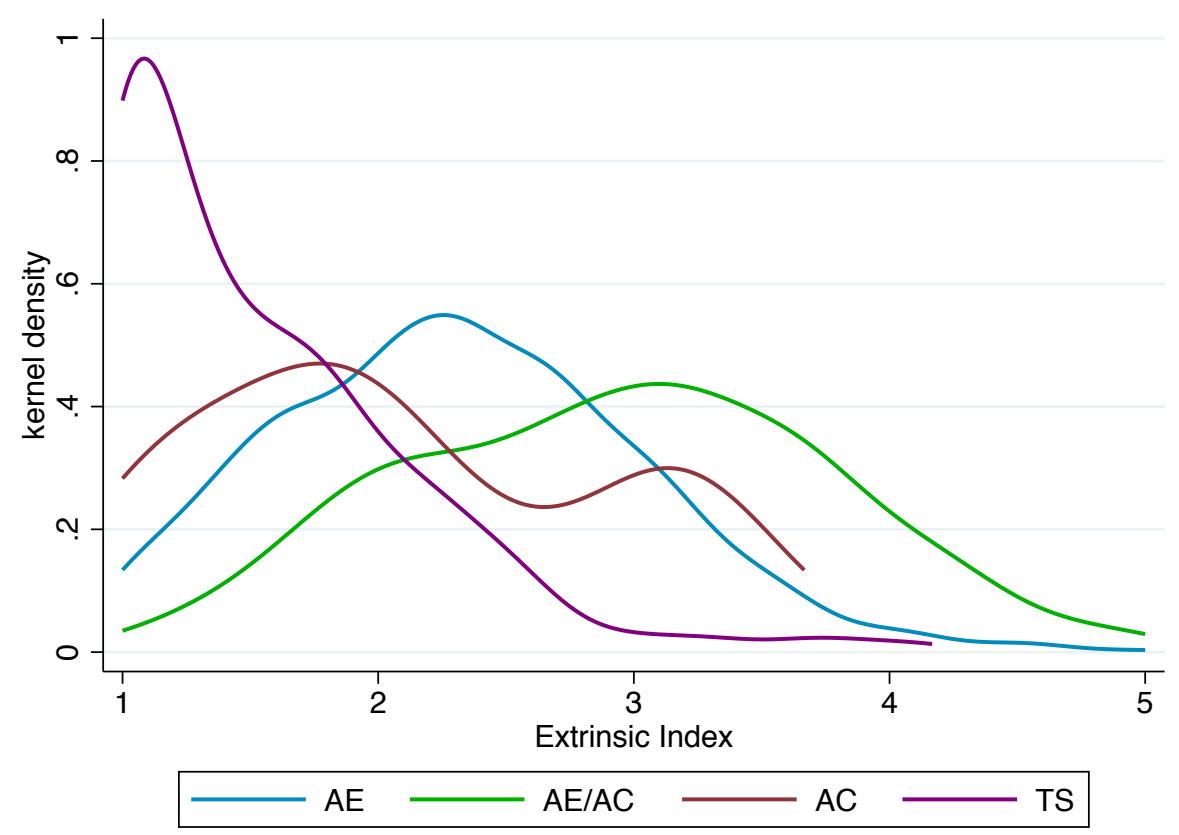

Note: This figure displays the distribution of the calculated intrinsic and extrinsic indexes from the cross-section data for individuals surveys both in 2005 and 2015, by UIR category. 


\section{Empirical Strategy and Results}

Descriptive statistics show remarkable differences in academic outputs across UIR categories as well as in factors shaping research topic choice. In order to isolate these relationships, we use regression techniques to estimate correlations between UIR categories and various university outputs. The models, which should be interpreted as correlational rather than causal, use Traditional Scholars (TS) as our comparison category.

In the first set of estimates, we explore individual and institutional determinants of UIR engagement, including the relative role of faculty motivations, and field and university specific effects, while controlling for faculty characteristics. We estimate Equation 1 using a linear probability model with standard errors clustered at the university level to account for university level heterskedasticity. Our dependent variable $U I R_{i f u}$ is a binary indicator variable for any UIR engagement, relative to traditional scholarship (TS). We adopt a flexible functional form to capture the potential correlation between motivation and UIR participation, $\sum_{k=1}^{k=4} Q_{k_{i}^{m}}$, with $m \in\{$ Int, Ext $\}$.

The regressors, $Q_{k} F^{m}$ are indicators for each quartile $k$ of each motivation $F^{m}$ distribution. We omit the first quartile: $Q_{1} F^{m}$. The vector $X$ measures individual characteristics and includes: gender, university appointment (professor, assistant professor or full professor), and an indicator for whether the scientist was awarded a Ph.D. from a land-grant institution. The variables $\mu_{f}$ and $\nu_{u}$ are field and university fixed effects, respectively.

$$
U I R_{i f u}=\alpha+\sum_{k=1}^{k=4} \beta_{k}^{S} Q_{k} F_{i}^{S c i}+\sum_{k=1}^{k=4} \beta_{k}^{C} Q_{k} F_{i}^{C o m}+\gamma X_{i}+\mu_{f}+\nu_{u}+\epsilon_{i f u}
$$

To demonstrate the correlations between UIR participation and our variables of interest which are all categorical we plot the effects in a series of figures. Figures 3 and 4 plot the set of estimated parameters for categorical variables, $\beta_{k}^{m}, \mu_{f}$ and $\nu_{u}$, which are respectively motivation categories, university effects, and field effects.

Figure 3 shows the parameter estimates for quartiles of the intrinsic and extrinsic motivation indexes on the probability that a faculty member engages in UIR activities. The figure shows 
estimated parameters for both unconditional (no other controls) and conditional (all controls in equation (1)) along with $95 \%$ confidence bands. The figure shows that as the intrinsic index increases the probability of doing UIR activities marginally decreases, with intrinsic motivation playing a small role differentiating UIR engagement. As for extrinsic motivation, there is a higher probability of UIR engagement as this indexes increases. These correlations corroborate the descriptive statistics that intrinsic motivation is high across the board whereas extrinsic motivation plays an important role in differentiating UIR engagement. Overall, these determinants are robust to the inclusion of a variety of controls.

In figure 4 we show how the estimated parameters on university fixed effects, estimated from equation (1) vary across university, with University of Wisconsin-Madison, which has the oldest technology transfer office among US universities as the baseline. There are high university specific effects, which indicate more UIR activity at that university, at some of the large LGU's such as Illinois, UC-Davis, Purdue, Iowa State. But we also see some smaller LGU's such as Alaska, Rutgers in the top tier. There are some surprising effects with UC-Berkeley and Cornell in the bottom tier along with a number of smaller LGU's that have fewer resources and newer traditions of UIR. Since we have controlled in these regressions for both individual and observable university characteristics, the best interpretation for these results is a measure of the UIR "culture" at these universities. Universities such as Cornell and UC-Berkeley may have stronger basic science cultures with less focus on UIR, while the large mostly midwestern LGU's that are high on the list may have stronger outreach and extension cultures which promotes more UIR.

The second half of the figure shows the estimated parameters on the field of specialty level fixed effects, with plant sciences, which is the largest category, as the baseline. The other production agriculture sciences, namely animal sciences, agricultural engineering, and food and nutrition studies are not statistically distinguishable from plant sciences. This result, likely driven by academic engagement in production agriculture fields, is expected. Ecology and basic biological sciences, however, show lower levels of UIR engagement than do plant sciences, despite those fields potentially having higher potential in commercialization. This may be due to the stronger basic science orientation of these fields relative to applied production sciences. And as one would expect the 
social sciences are at the lowest levels of all of the agriculture and life science college disciplines in terms of UIR activities.

Figure 3: Linear probability model: (any) UIR engagement by quartile of attitudes

(a) Quartiles of Intrinsic Index

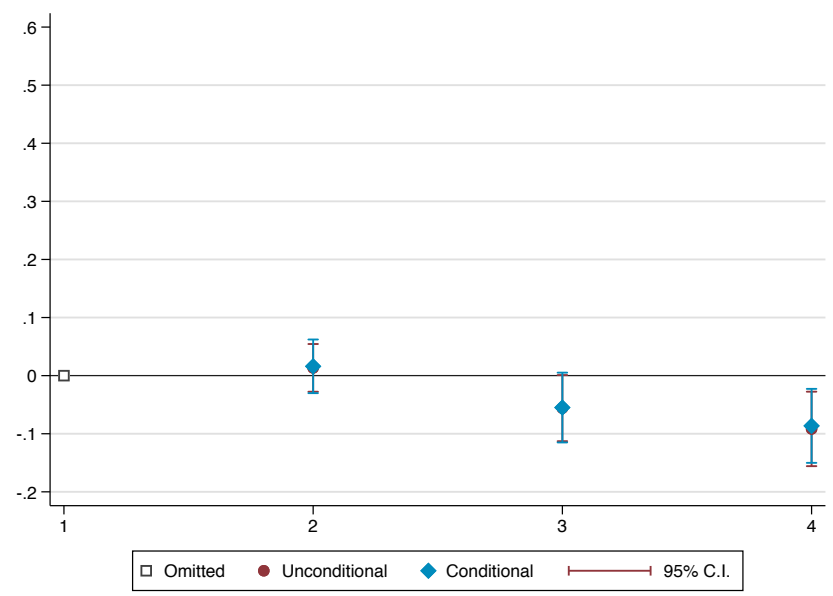

(b) Quartiles of Extrinsic Index

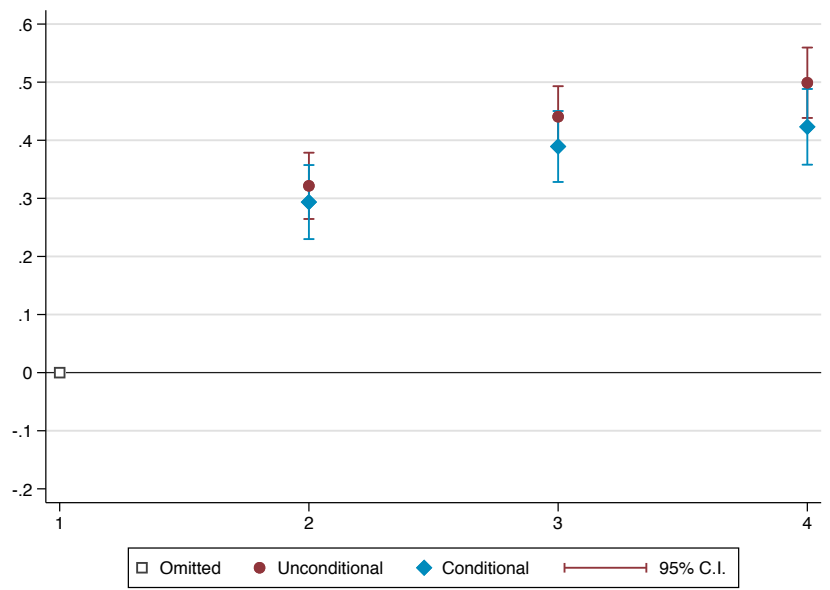

Note: coefficients are for quartiles of motivation, with the first quartile as omitted variable. Dependent variable is an indicator for whether individual engages in any UIR type (1) as opposed to being a traditional scholar (0). Unconditional estimates includes a survey year dummy. Controls for the conditional estimates include: gender, position as professor, a dummy for whether $\mathrm{PhD}$ was in a land grant institution, field (plant science, $\mathrm{Ag} / \mathrm{Engineering}$, animal science, biology, ecology, food/nutrition, and sociology), and university fixed effects, which correspond to the 52 land-grant universities. Standard errors are clustered at the university level. 
Figure 4: Linear probability model of UIR engagement - Field and University Fixed Effects.

(a) University estimated FE

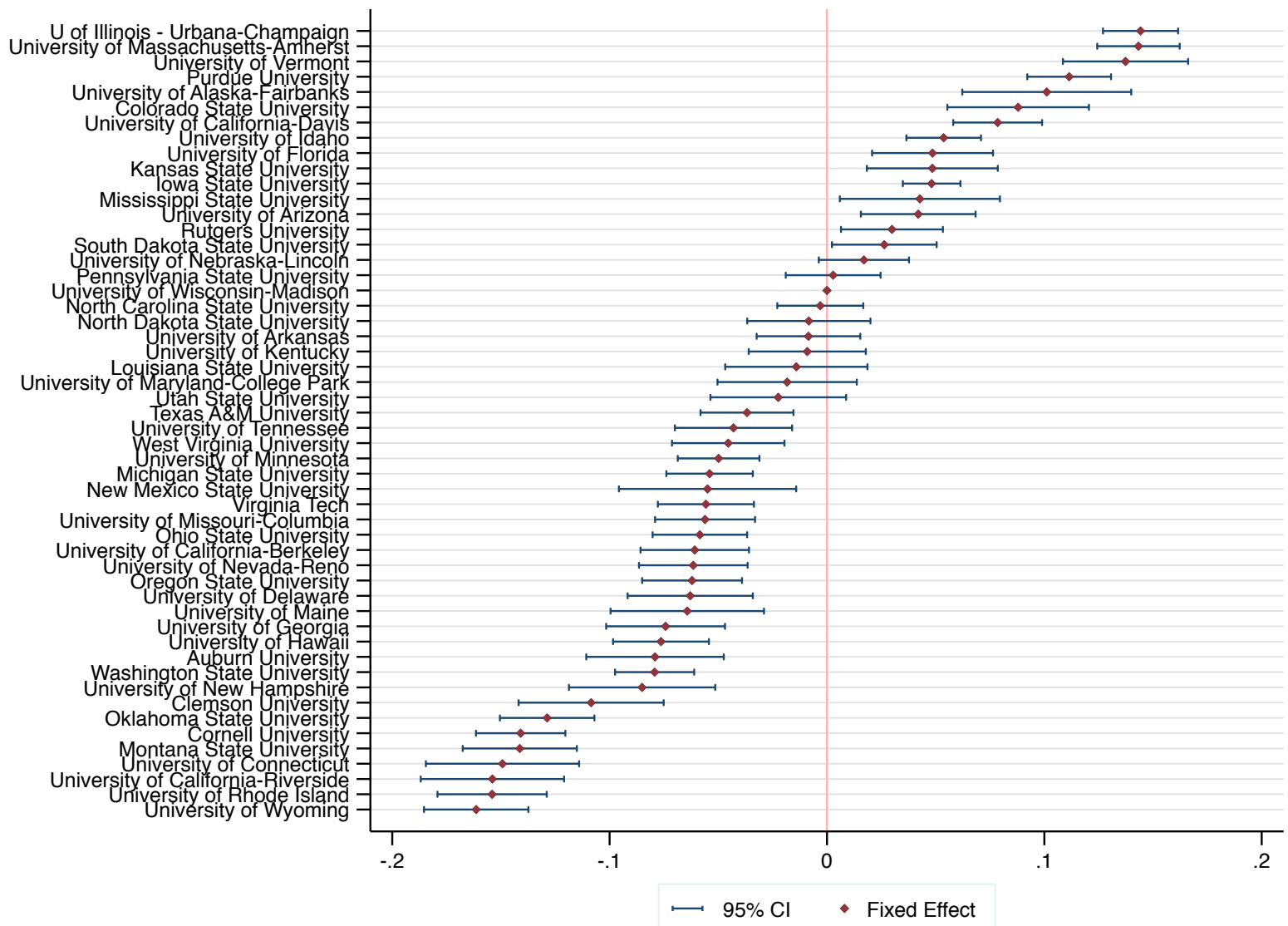

(b) Field estimated FE

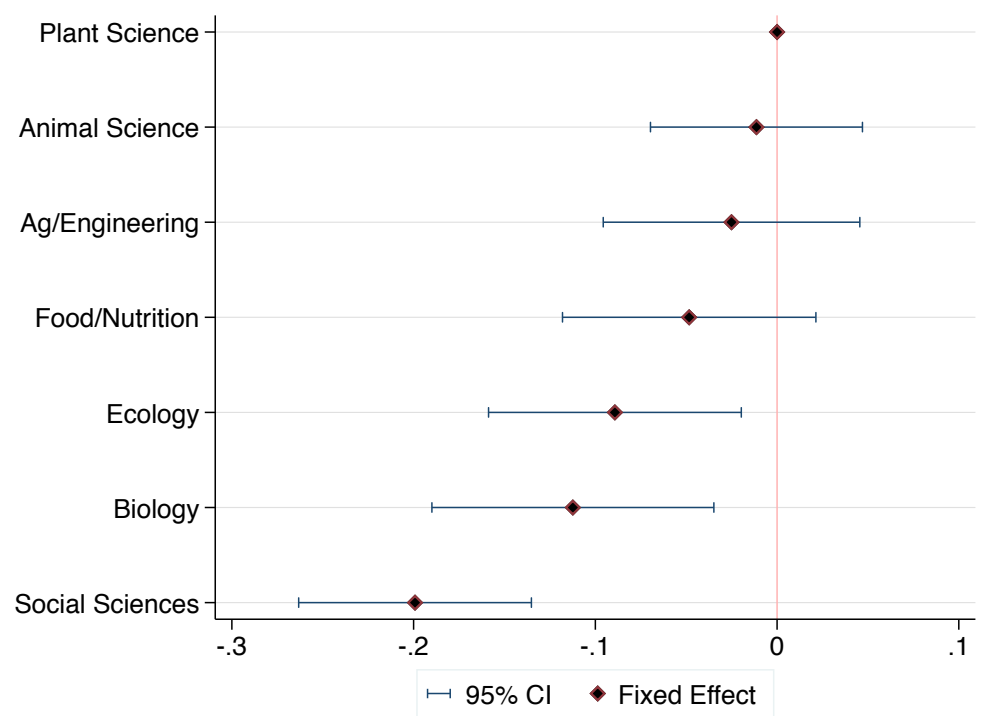

Note: For both panels, dependent variable is an indicator for whether individual engages in any UIR type (1) as opposed to being a traditional scholar (0). (a) coefficients are for 52 university indicators, with UW-Madison as omitted variable. (b) coefficients are for field indicators, with plant science as the omitted variable. We choose plant science as the omitted variables for being the most popular field in our sample. Additional controls include: gender, position as professor, a dummy for whether $\mathrm{PhD}$ was in a land grant institution. Standard errors are clustered at the university level. 
In a second set of regression estimates, we isolate how each type of UIR activity correlates with academic productivity. The uniqueness of our dataset allows us to control for an often unobserved dimension of individual heterogeneity: faculty motivations, both intrinsic and extrinsic, allowing for direct effects of these characteristics besides its effects through UIR engagement. We also control for individual, field and institutional characteristics.

We estimate different versions of Equation 2, in which $Y_{i f u}$ varies in each regression covering: number of journal articles, Ph.D. graduates and total funding for scientist $i$ in field $f$ at university u. $\mathrm{AC}, \mathrm{AE} / \mathrm{AC}$ and $\mathrm{AE}$ are our mutually exclusive measures of UIR and traditional scholars is the omitted baseline category. The values $F_{i}^{I}$ and $F_{i}^{E}$ are the index scores for intrinsic and extrinsic motivation, respectively. The vector $X$ measures individual characteristics and includes: gender, university appointment (professor, assistant professor or full professor), and an indicator for whether the scientist was awarded a Ph.D. from a land-grant institution. The variables $\mu_{f}$ and $\nu_{u}$ are field and university fixed effects, respectively. Equation 2 is as follows:

$$
Y_{i f u}=\alpha+\beta_{1} A C+\beta_{2} A E / A C+\beta_{3} A E+\psi_{S} F_{i}^{S}+\psi_{C} F_{i}^{C}+\gamma X_{i}+\mu_{f}+\nu_{u}+\epsilon_{i f u}
$$

The standard errors are clustered at the university level to control for university level heteroskedasticity.

Table 10 shows the results of estimating equation (1) with journal articles and Ph.D. students produced over the last five years as the dependent variable. The columns provide increasing levels of control variables, with a first column the baseline, the second adds in our motivational measures, the third individual controls, and the fourth field and university fixed effects. Across all models one sees two dominant statistically significant and large effects, which are (i) that compared to traditional scholars, $\mathrm{AE} / \mathrm{AC}$ and $\mathrm{AC}$ only faculty produce more journal articles and more Ph.D. students and (ii) that levels of "intrinsic motivations" are directly correlated with both journal articles and $\mathrm{PhD}$ students whereas extrinsic (commercial) motivations do not play a direct role besides those embedded in how they determine UIR participation. Overall the picture that emerges from Table 10 is that UIR faculty, especially those with commercial ties are more productive than 
traditional scholars. In addition, those in the AE-only category appear to produce scholarship and students at about the level of traditional scholars.

Table 10: OLS estimates - Journal articles publications and PhD graduates under supervision, 2005 and 2015 pooled.

\begin{tabular}{|c|c|c|c|c|c|c|c|c|}
\hline \multirow[b]{2}{*}{ AE only } & \multicolumn{4}{|c|}{ Journal Articles } & \multicolumn{4}{|c|}{ PhD Graduates } \\
\hline & $\begin{array}{c}0.288 \\
(0.757)\end{array}$ & $\begin{array}{c}1.240 \\
(0.807)\end{array}$ & $\begin{array}{c}1.053 \\
(0.829)\end{array}$ & $\begin{array}{c}0.385 \\
(0.772)\end{array}$ & $\begin{array}{c}-0.297^{*} \\
(0.154)\end{array}$ & $\begin{array}{c}-0.044 \\
(0.151)\end{array}$ & $\begin{array}{l}-0.044 \\
(0.138)\end{array}$ & $\begin{array}{c}0.093 \\
(0.125)\end{array}$ \\
\hline $\mathrm{AE} / \mathrm{AC}$ & $\begin{array}{c}7.062^{* * *} \\
(1.147)\end{array}$ & $\begin{array}{c}7.325^{* * *} \\
(1.125)\end{array}$ & $\begin{array}{c}6.614^{* * *} \\
(1.109)\end{array}$ & $\begin{array}{c}4.747^{* * *} \\
(1.152)\end{array}$ & $\begin{array}{l}0.353^{*} \\
(0.186)\end{array}$ & $\begin{array}{c}0.633^{* * *} \\
(0.196)\end{array}$ & $\begin{array}{c}0.477^{* *} \\
(0.188)\end{array}$ & $\begin{array}{c}0.539^{* * *} \\
(0.161)\end{array}$ \\
\hline $\mathrm{AC}$ only & $\begin{array}{c}6.336^{* *} \\
(2.400)\end{array}$ & $\begin{array}{l}5.698^{* *} \\
(2.498)\end{array}$ & $\begin{array}{c}6.281^{* *} \\
(2.424)\end{array}$ & $\begin{array}{c}5.100^{* *} \\
(2.278)\end{array}$ & $\begin{array}{c}0.452 \\
(0.369)\end{array}$ & $\begin{array}{c}0.474 \\
(0.381)\end{array}$ & $\begin{array}{c}0.561 \\
(0.344)\end{array}$ & $\begin{array}{l}0.735^{* *} \\
(0.361)\end{array}$ \\
\hline Intrinsic Motivation & & $\begin{array}{c}3.722^{* * *} \\
(0.574)\end{array}$ & $\begin{array}{c}4.041^{* * * *} \\
(0.578)\end{array}$ & $\begin{array}{c}3.587^{* * * *} \\
(0.592)\end{array}$ & & $\begin{array}{c}0.444^{* * *} \\
(0.088)\end{array}$ & $\begin{array}{c}0.514^{* * * *} \\
(0.085)\end{array}$ & $\begin{array}{c}0.480^{* * * *} \\
(0.091)\end{array}$ \\
\hline Extrinsic Motivation & & $\begin{array}{c}0.381 \\
(0.452)\end{array}$ & $\begin{array}{c}0.358 \\
(0.441)\end{array}$ & $\begin{array}{c}0.419 \\
(0.472)\end{array}$ & & $\begin{array}{c}-0.136^{*} \\
(0.074)\end{array}$ & $\begin{array}{l}-0.088 \\
(0.071)\end{array}$ & $\begin{array}{l}-0.029 \\
(0.063)\end{array}$ \\
\hline Survey year & $\mathrm{x}$ & $\mathrm{x}$ & $\mathrm{x}$ & $\mathrm{x}$ & $\mathrm{x}$ & $\mathrm{x}$ & $\mathrm{x}$ & $\mathrm{x}$ \\
\hline Individual Controls & & & $\mathrm{x}$ & $\mathrm{x}$ & & & $\mathrm{x}$ & $\mathrm{x}$ \\
\hline Field/University FE & & & & $\mathrm{x}$ & & & & $\mathrm{x}$ \\
\hline Observations & 1,479 & 1,479 & 1,479 & 1,479 & 1,479 & 1,479 & 1,479 & 1,479 \\
\hline R-squared & 0.070 & 0.110 & 0.153 & 0.223 & 0.024 & 0.049 & 0.174 & 0.271 \\
\hline p-value F-test $(\mathrm{UIR}=0)$ & 0.00 & 0.00 & 0.00 & 0.00 & 0.14 & 0.01 & 0.03 & 0.00 \\
\hline
\end{tabular}

Note: coefficients on UIR categories are relative to traditional scholars (omitted). AE $=$ Academic Engagement; AC $=$ Academic Commercialization. Dependent variables are total of articles published in the last 5 years and number of $\mathrm{PhD}$ graduates under supervision in the last 5 years. Individual controls include: gender, position as professor, and a dummy for whether $\mathrm{PhD}$ was in a land grant institution. Field includes: plant science, Ag/Engineering, animal science, biology, ecology, food/nutrition, and sociology. University fixed effects correspond to the 52 land-grant universities. Standard errors are clustered at the university level. ${ }^{* * *} \mathrm{p}<0.01,{ }^{* *} \mathrm{p}<0.05,{ }^{*} \mathrm{p}<0.10$.

Table 11 shows the results of estimating equation (1) with total funding and public funding as the dependent variable. It is worth noting that our categories of UIR are partially created with funding data, so we should expect a positive relationship with total funding, though not with public funding. Here we see very strong and statistically significant correlations of any UIR activity with both total funding and federal funding. While the former is somewhat expected, the latter suggests that rather than be a distraction from traditional scholarship directions, faculty engagement in UIR activities is synergistic in terms of bringing in federal funding which is generally associated with traditional scholarship. Again, we see strong correlations of intrinsic motivations 
with both total and federal funding, suggesting a direct effect whereas extrinsic motivation does not.

Table 11: OLS estimates - Total and Public Funding, 2005 and 2015 pooled.

\begin{tabular}{|c|c|c|c|c|c|c|c|c|}
\hline \multirow[b]{2}{*}{ AE only } & \multicolumn{4}{|c|}{ Total Funding (IHS) } & \multicolumn{4}{|c|}{ Public Funding (IHS) } \\
\hline & $\begin{array}{c}1.024 * * * \\
(0.259)\end{array}$ & $\begin{array}{c}1.231^{* * *} \\
(0.266)\end{array}$ & $\begin{array}{c}1.218^{* * *} \\
(0.269)\end{array}$ & $\begin{array}{c}1.164^{* * *} \\
(0.252)\end{array}$ & $\begin{array}{c}0.693^{* *} \\
(0.341)\end{array}$ & $\begin{array}{c}1.299^{* * *} \\
(0.368)\end{array}$ & $\begin{array}{c}1.250^{* * *} \\
(0.364)\end{array}$ & $\begin{array}{c}1.368^{* * *} \\
(0.341)\end{array}$ \\
\hline $\mathrm{AE} / \mathrm{AC}$ & $\begin{array}{c}1.935 * * * \\
(0.265)\end{array}$ & $\begin{array}{c}1.970^{* * *} \\
(0.290)\end{array}$ & $\begin{array}{c}1.955^{* * *} \\
(0.294)\end{array}$ & $\begin{array}{c}1.786^{* * *} \\
(0.286)\end{array}$ & $\begin{array}{c}1.474^{* * *} \\
(0.412)\end{array}$ & $\begin{array}{c}2.124^{* * * *} \\
(0.480)\end{array}$ & $\begin{array}{c}2.044^{* * *} \\
(0.477)\end{array}$ & $\begin{array}{c}1.999^{* * *} \\
(0.475)\end{array}$ \\
\hline AC only & $\begin{array}{c}1.695^{* * * *} \\
(0.383)\end{array}$ & $\begin{array}{c}1.535^{* * *} \\
(0.391)\end{array}$ & $\begin{array}{c}1.593^{* * *} \\
(0.391)\end{array}$ & $\begin{array}{c}1.367^{* * *} \\
(0.398)\end{array}$ & $\begin{array}{c}1.692^{* *} \\
(0.659)\end{array}$ & $\begin{array}{c}1.725^{* *} \\
(0.657)\end{array}$ & $\begin{array}{c}1.899^{* * *} \\
(0.643)\end{array}$ & $\begin{array}{c}1.871^{* * *} \\
(0.693)\end{array}$ \\
\hline Intrinsic Motivation & & $\begin{array}{c}0.871^{* * *} \\
(0.116)\end{array}$ & $\begin{array}{c}0.866^{* * * *} \\
(0.121)\end{array}$ & $\begin{array}{c}0.730^{* * *} \\
(0.113)\end{array}$ & & $\begin{array}{c}1.113^{* * *} \\
(0.188)\end{array}$ & $\begin{array}{c}1.137^{* * *} \\
(0.193)\end{array}$ & $\begin{array}{c}0.936^{* * *} \\
(0.188)\end{array}$ \\
\hline Extrinsic Motivation & & $\begin{array}{c}0.109 \\
(0.094)\end{array}$ & $\begin{array}{c}0.070 \\
(0.096)\end{array}$ & $\begin{array}{c}0.196^{*} \\
(0.106)\end{array}$ & & $\begin{array}{c}-0.302^{*} \\
(0.180)\end{array}$ & $\begin{array}{l}-0.336^{*} \\
(0.182)\end{array}$ & $\begin{array}{l}-0.118 \\
(0.188)\end{array}$ \\
\hline Survey year & $\mathrm{x}$ & $\mathrm{x}$ & $\mathrm{x}$ & $\mathrm{x}$ & $\mathrm{x}$ & $\mathrm{x}$ & $\mathrm{x}$ & $\mathrm{x}$ \\
\hline Individual Controls & & & $\mathrm{x}$ & $\mathrm{x}$ & & & $\mathrm{x}$ & $\mathrm{x}$ \\
\hline Field/University FE & & & & $\mathrm{x}$ & & & & $\mathrm{x}$ \\
\hline Observations & 1,479 & 1,479 & 1,479 & 1,479 & 1,479 & 1,479 & 1,479 & 1,479 \\
\hline R-squared & 0.052 & 0.096 & 0.107 & 0.168 & 0.014 & 0.045 & 0.061 & 0.124 \\
\hline $\mathrm{p}$-value $\mathrm{F}$-test $(\mathrm{UIR}=0)$ & 0.00 & 0.00 & 0.00 & 0.00 & 0.00 & 0.00 & 0.00 & 0.00 \\
\hline
\end{tabular}

Note: coefficients on UIR categories are relative to traditional scholars (omitted). AE = Academic Engagement; $\mathrm{AC}=$ Academic Commercialization. Dependent variables current annual budget and its subcategory of total public funding. Total public funding categories are USDA, NSF, NIH, other federal agencies, and state agencies. Individual controls include: gender, position as professor, and a dummy for whether $\mathrm{PhD}$ was in a land grant institution. Field includes: plant science, Ag/Engineering, animal science, biology, ecology, food/nutrition, and sociology. University fixed effects correspond to the 52 land-grant universities. Standard errors are clustered at the university level. *** $\mathrm{p}<0.01,{ }^{* *} \mathrm{p}<0.05,{ }^{*} \mathrm{p}<0.10$.

\section{Discussion}

Our empirical findings present a number of new findings for the study of UIR activities at U.S. universities on a number of important fronts. First, faculty participation rates in UIR activity are quite high; generally, around 70-80\% of U.S. LGU agricultural and life scientists engage in AE, AC, or both. Second, faculty participation in UIR is predominantly in the area of academic engagement (AE), the more traditional type of research collaboration involving sponsored research, industry collaboration (including farmers and their commodity organizations), and other types of research exchanges (presentations and shared problem identification). In fact, only about 2-3\% of faculty 
in either the 2005 or 2015 survey participated in just AC activities. Third, as a source of research funding for agricultural and life science faculty at U.S. LGUs, AE industry revenues completely dominate $\mathrm{AC}$ license revenues, but the largest individual faculty funding levels come from those who do both $\mathrm{AE}$ and $\mathrm{AC}$. Overall, patent license revenues provide about $1 \%$ of lab revenues, as compared to close to a $20 \%$ share for industry and commodity group funds. This funding outcome appears to be in 'steady-state' now thirty-five years after the passage of the Bayh-Dole Act and more than twenty-five years after the takeoff of US public university patenting activity, as the ratio of AE to AC funding was the same in 2015 as it was in 2005.

This study also finds descriptive evidence that UIR activities are highly correlated and likely synergistic with traditional academic scholarship activities. This outcome is consistent with previous studies that find the more productive researchers are also often the ones most highly "in demand' or active in UIR activities. While this study does not undertake the type of longitudinal dynamic statistical analysis of Sengupta and Ray (2017) who find positive feedbacks between AE and research outcomes at the university level, prima facie evidence presented in our work at the individual faculty level is consistent with that outcome. In particular our finding that the AE/AC faculty persist across time periods and that this group has more research revenues and higher publication and student counts, demonstrates this individual positive feedback loop.

In examining factors shaping the participation of U.S.-LGU faculty with UIR activities, we find that institutional factors, specifically 'fields' or 'disciplines' are a significant conditioning factor, with more applied science fields like plant and animal sciences having higher UIR rates than more basic ones like biological and ecological ones. Most of the differences in UIR activity by fields are driven by variations in $\mathrm{AE}$ rather than $\mathrm{AC}$ as shown in the UIR activity regressions. This finding is consistent both with the lower overall participation in $\mathrm{AC}$ and the fact that most of the faculty active in $\mathrm{AC}$ are also active in $\mathrm{AE}$. The reverse is not true. Most faculty engaged in $\mathrm{AE}$ are not active in AC. In this regard, it appears that AC may be somewhat opportunistic, and may depend on the types of inventions or discoveries being made by scientists. Put simply, ongoing collaboration with industry or sponsored research arrangements may, from time to time, give rise to the pursuit of invention disclosures and patents, and so entry and exit into AC activities appears 
to occur regularly as shown in the transition matrix in Table 5 above.

The most substantive individual factors shaping the intensity of participation in UIR appear to be faculty 'attitudes' with respect to research problem choice. While we do not attempt here to identify a causal relationship between attitudes and UIR activity involvement, agricultural and life science faculty at U.S.-LGUs report that their research problem choices are strongly driven by intrinsic factors, such as curiosity or the potential to contribute to scientific theory relative to intrinsic motives. This is true across all of the UIR categories used here, though what distinguishes the $\mathrm{AE}, \mathrm{AC}$, and $\mathrm{AE} / \mathrm{AC}$ from TS is a somewhat stronger level of extrinsic motive. This basic preference for science has been a consistent outcome across decades of surveys of U.S.-LGU faculty and is consistent also with the continued importance of federal, competitive grants as a primary source of research funding.

Finally, university fixed-effect measures in our UIR regressions reveal statistically significant differences in university "cultures" with respect to UIR. These differences appear to relate to the timing of initial commercialization activity and potentially to other historical and locational factors that could be important for how they shape faculty behavior over time. This is an area of ongoing interest and potentially productive future inquiry.

\section{Conclusion}

This article has examined the university-industry relations activities of agricultural and life science faculty at the premier U.S. Land Grant Universities, using survey data gathered from large, random and longitudinal samples in 2005 and 2015. The analysis of this unique set of data fills an empirical gap identified in the literature by carefully exploring the relative importance of academic engagement and academic commercialization. Because U.S. LGUs are 'ground-zero' of U.S. public research university University-Industry-Relations activities, the empirical context is of broader significance to the U.S. and beyond. We have found descriptive and correlational evidence that traditional academic scholarship has not systematically been distorted or constrained in the ways that some originally feared, and that UIR while important to faculty, universities, and society 
is not a fundamental threat to the advancement of science.

At U.S. Land Grant Universities, the longstanding tradition of academic engagement, involving sponsored research and direct collaboration with scientists and managers in industry and agriculture, dominate the new academic commercialization relationships in prevalence and importance for faculty research funding. Moreover, these two types of UIR appear to be complements, with AC being an occasional outgrowth of AE in some fields and for some faculty, which likely depends on the continuity of AE relationships to emerge. Seen in this way, the UIR activities of agricultural and life scientists at LGUs is more of a natural outgrowth of the Land-Grant system's traditional model of working with industry to foster improved outcomes in their own states and the nation. Fears of UIR subverting the LGU mission appear to be misplaced. Rather we find that UIR complements the traditional scholarship of top scholars in agricultural and life science fields in part by helping them access more funding and connections with industries in their field.

Future research with these data will attempt to pursue causal identification of UIR participation and intensity outcomes using historical information as instruments as well as more exploitation of the panel data. Expanding the focus on university-level factors seems worth special attention in this effort. In addition, given the significant growth in the proportion of women and foreign faculty in the U.S. LGUs over time, there are open important questions as to whether this has changed the dynamics of UIR participation. 


\section{References}

Agrawal, A.K., 2001. University-to-industry knowledge transfer: Literature review and unanswered questions. International Journal of management reviews 3, 285-302.

Agarwal, A., Henderson R.M., 2002. Putting patents in context: exploring knowledge transfer from MIT. Management Science 48, 44-60.

American Academy of Arts \& Sciences, 2016. Public research universities: Understanding the financial model, Cambridge, MA.

Azoulay, P., Ding, W., Stuart, T. 2007. The determinants of faculty patenting behavior: demographics or opportunities? Journal of Economic Behavior and Organization 63, 599612.

Barham, B., Foltz, J., Agnes, M., van Rijn, J., 2017. Modern agricultural science in transition: a survey of U.S. Land Grant agricultural and life scientists, Staff paper 585, Agricultural and Applied Economics, UW-Madison.

Barham, B., Foltz, J., Prager, D., 2014. Making time for science. Research Policy. 43, 21-31.

Barham, B., Foltz, J., Kim, K. ,2002. Trends in university agbiotech patent production. Review of Agricultural Economics 24: 294-308.

D'Este, P., Perkmann, M., 2011. Why do academics engage with industry? The entrepreneurial university and individual motivations. Journal of Technology Transfer 36, 316-339.

Dillman, D. A., 2011. Mail and Internet surveys: The tailored design method-2007 Update with new Internet, visual, and mixed-mode guide. John Wiley \& Sons.

Djokovic, D., Souitaris, V., 2008. Spinouts from academic institutions: a literature review with suggestions for further research. The Journal of Technology Transfer 33, 225-247. 
Ehrenberg, R., 2012. American higher education in transition. Journal of Economic Perspectives 26, 193-216

Fitzgerald, H. E., Bruns, K., Sonka, S., Furco, A., Swanson, L., 2012. The centrality of engagement in higher education. Journal of Higher Education Outreach and Engagement $16,7-28$.

Foltz, J., Kim, K., Barham, B., 2003. A dynamic analysis of university agricultural biotechnology patents. American Journal of Agricultural Economics 85, 187-197.

Foltz, J.,\& Barham, B., 2009. The productivity effects of extension appointments in landgrant colleges. Review of Agricultural Economics 31, 712-733.

Geuna, A., Nesta, L., 2006. University patenting and its effects on academic research: the emerging European evidence. Research Policy 35: 790-807.

Geuna, A., Muscio, A., 2009. The governance of university knowledge transfer: A critical review of the literature. Minerva 47, 93-114.

Grimaldi, R., Kenney, M., Siegel, D., Wright, M., 2011. 30 years after Bayh-Dole: Reassessing academic entrepreneurship. Research Policy 40, 1045-1057.

Henderson, R, Jaffe, A, and Trajtenberg, M., 1998. Universities as a source of commercial technology: a detailed analysis of university patenting, 1965-1988, Review of Economic Statistics 80, 119-27.

Hoag, D. L., 2005. WAEA Presidential Address: Economic principles for saving the Cooperative Extension Service. Journal of Agricultural and Resource Economics, 397-410.

Just, R. E., Huffman, W. E., 2009. The economics of universities in a new age of funding options. Research Policy 38, 1102-1116.

Mitchell, M., Palacios, V., Leachman, M., 2015. States are still funding higher education below pre-recession levels. Journal of Collective Bargaining in the Academy, Vol. 0, Iss. 10 [2015], Art. 71. 
Perkmann, M., King, Z., Pavelin, S., 2011. Engaging excellence? Effects of faculty quality on university engagement with industry. Research Policy 40, 539-552.

Perkman, M, Tartari, V, McKelvey, M, Autio, E, Brostrom, A, D’Este, P, Fini, R, Geuna, A, Grimaldi, R, Hughes, A, Krabel, S, Kitson, M, Llerena, P, Lissoni, F, Salter, A, Sobrero, M., 2013. Academic engagement and commercialisation: a review of the literature on universityindustry relations. Research Policy 42, 423-42.

Phan, P., Siegel, D., 2006. The effectiveness of university technology transfer. Foundations and Trends in Entrepreneurship. 2, 77-144.

Prager, D.L., Foltz, J.D. Barham, B.L., 2014. Making time for agricultural and life science research: technical change and productivity gains. American Journal of Agricultural Economics 97,743-761.

Sampat, B., 2006. Patenting and US academic research in the 20th century: The world before and after Bayh-Dole. Research Policy 35, 772-789.

Sengupta, A., Ray, A. S., 2017. University research and knowledge transfer: a dynamic view of ambidexterity in british universities. Research Policy 46, 881-897.

Tartari, V., Perkmann, M., Salter, A., 2014. In good company: the influence of peers on industry engagement by academic scientists. Research Policy 43, 1189-1203.

Tartari, V., Salter, A., 2015. The engagement gap: Exploring gender differences in UniversityIndustry collaboration activities. Research Policy 44, 1176-1191

Thursby, J,Thursby, M., 2011. Has the Bayh-Dole Act compromised basic research? Research Policy 40,1077-83.

van den Besselaar, P., SandstrÂüm, U., 2017. Vicious circles of gender bias, lower positions, and lower performance: Gender differences in scholarly productivity and impact. PloS one, 12(8), e0183301. 
Zucker, L. , Darby, M., 1996. Star scientists and institutional transformation: Patterns of invention and innovation in the formation of the biotechnology industry. Proceedings of the National Academy of Sciences, 93: 12709-12716. 


\section{A. Sample selection and imputation of missing values}

\begin{tabular}{lcc}
\hline \hline & $\mathbf{2 0 0 5}$ & $\mathbf{2 0 1 5}$ \\
Random Sample & 1,960 & 2,315 \\
Sample completed survey & 1,180 & 711 \\
drop field=other & 1,153 & 704 \\
drop not professor & 1,107 & 680 \\
drop cross-missing & 881 & 598 \\
Final Sample & $\mathbf{8 8 1}$ & $\mathbf{5 9 8}$ \\
\hline \hline
\end{tabular}

Within the sample of individual who completed the survey, there was a large number of missing values. We assumed a set of hypothesis in order to impute values. (i) Research attitudes: Likert scale ranging from 0 to 5 . We assigned a neutral value, "3", if the individual answered the block at least partially. When all items are missing, variables remain missing; (ii) UIR related measures: assigned zero to missing when the person answered part of the block. When all are missing, variables remain missing; (iii) Extension and Outreach: as long as the block is not all missing, missing values are replaces as zero; (iv) PhD Students: if block is not all missing, value is set to zero; For each block, we calculated the total number of imputed values and results are robust to adding these variables in the regression as a control. Results upon request. 